Article

\title{
Restoring the Reactivity of Organic Acid Solution Used for Silver Recovery from Solar Cells by Fractional Distillation
}

\author{
Jun-Kyu Lee ${ }^{1}$, Jin-Seok Lee ${ }^{1, * \mathbb{D}}$, Young-Soo Ahn ${ }^{1}$ and Gi-Hwan Kang ${ }^{2}$ \\ 1 Separation and Conversion Materials Laboratory, Korea Institute of Energy Research, Daejeon 34129, Korea \\ 2 Photovoltaic Laboratory, Korea Institute of Energy Research, Daejeon 34129, Korea \\ * Correspondence: jslee@kier.re.kr; Tel.: +82-42-860-3745; Fax: +82-42-860-3133
}

Received: 30 May 2019; Accepted: 1 July 2019; Published: 3 July 2019

check for updates

\begin{abstract}
Methanesulfonic acid (MSA) is used to recover silver (Ag) from solar cells by adding an oxidizing agent. It is possible to regenerate by substituting of $\mathrm{H}^{+}$for $\mathrm{Ag}^{+}$, and thus it can be reused for additional reactions. However, MSA is highly hygroscopic, and as an oxidizing agent can easily decompose in the acidic environment during Ag extraction, leading to dilution due to the formation of $\mathrm{H}_{2} \mathrm{O}$. This $\mathrm{H}_{2} \mathrm{O}$ in the MSA solution hinders the Ag extraction. In this study, we present a fractional distillation process for restoring the reactivity of reused MSA solutions by reducing the $\mathrm{H}_{2} \mathrm{O}$ content. Our results showed that the reactivity of the separated MSA was restored and Ag could be recovered from the solar cell.
\end{abstract}

Keywords: solar cell; silver; methanesulfonic acid; fractional distillation

\section{Introduction}

The disposal of wastes associated with end-of-life (EoL) photovoltaic (PV) modules is problematic [1]. In general, the lifespan of a crystalline silicon (c-Si) PV module is 25-30 years, and it has been installed since the 1990s [2]. This means that the disposal of EoL PV modules will increase rapidly. In this regard, the IEA-PVPS (International Energy Agency-Photovoltaic Power Systems Programme) and IRENA (International Renewable Energy Agency) reported that the global waste generated from EoL PV modules is expected to reach 1.7-8 million tonnes by 2030 and 60-78 million tonnes by 2050 [3]. Therefore, a method to properly process PV modules is required. The European Union published the 2012/19/EU Directive, which includes guidelines on the handling of EoL PV modules. EoL PV modules are designated as waste electrical and electronic equipment (WEEE), so programs must be in place for their collection, recovery, and recycling [4]. For this reason, many recycling processes have been investigated for recovering valuable materials from PV modules with different levels of technologies [5-9]. In general, c-Si PV modules mostly comprise a piece of glass with aluminum frames, c-Si solar cells, an encapsulant, a back sheet, and a junction box. As Ag has a very low total weight in a PV module, it has not been considered worth recovering [10]. However, Ag is a very valuable material and has a relative value of almost half the cost of making PV modules [3]. For this reason, some studies have reported on the recovery of Ag from PV module components [11-18], including extraction with inorganic acid $[17,18]$. However, this method is not environmentally friendly, as it results in the generation of waste solutions. Meanwhile, Yang et al. [19] reported the recovery of Ag from c-Si solar cells by using eco-friendly methanesulfonic acid (MSA) solutions. MSA has a lot of advantages; for example, it is easy to handle, and has high conductivity, high metal salt solubility, and low toxicity [20]. However, since MSA is more expensive than conventional inorganic acids, a process that can reuse MSA must be developed for MSA-based Ag recovery to be competitive. However, it is 
expected that the process of recovering Ag using MSA has a side reaction to generate $\mathrm{H}_{2} \mathrm{O}$ and the reactivity of MSA will decrease. In addition, $\mathrm{H}_{2} \mathrm{O}$ is added during the process because MSA is highly hygroscopic. In this study, we explored possibilities of MSA solution reuse after recovering Ag using an MSA solution. Reusing the MSA can have significant economic improvements. Previous studies have already reported that reusing an acid solution is of great economic value [21,22]. Moreover, the economic value of $\mathrm{Ag}$ is large because, as previously mentioned, it is one of the most valuable elements on Earth. For this reason, the recovery of Ag through MSA reuse is very meaningful from an economic point of view. Meanwhile, previous studies have confirmed the side reactions in which $\mathrm{H}_{2} \mathrm{O}$ is generated during the $\mathrm{Ag}$ recovery process using MSA. Because the generated $\mathrm{H}_{2} \mathrm{O}$ can lower the acid concentration and decrease the reactivity, even if the metal solubility of the MSA is high, it can have a negative effect on the reuse of the MSA solution. Therefore, the separation behavior of MSA and $\mathrm{H}_{2} \mathrm{O}$ was investigated by fractional distillation. As a result, it was confirmed that MSA can be reused using the optimum fractional distillation conditions. Finally, $2 \mathrm{~N}$ grade Ag was recovered from $6 "$ commercial solar cells by MSA solution with restored reaction by fractional distillation.

\section{Materials and Methods}

\subsection{Recovery of Ag Using Reused Organic Solvent}

A 6" mono c-Si commercial solar cell was applied to confirm the reuse of the MSA solution. The solar cell was broken into many pieces, which were immersed in a reused MSA solution with $\mathrm{H}_{2} \mathrm{O}_{2}$ (30 wt.\%) for 1-12 h. The ratio of reused MSA and $\mathrm{H}_{2} \mathrm{O}_{2}$ was used 90:10. The stirring speed was $80 \mathrm{RPM}$ and the experiment proceeded at $25^{\circ} \mathrm{C}$.

\subsection{Fractional Distillation of Organic Compounds}

A 1:1 mixture of MSA and $\mathrm{H}_{2} \mathrm{O}$ was used to investigate the optimum conditions for the separation behavior of $\mathrm{H}_{2} \mathrm{O}$. A rotary evaporator (Hahnshin S\&T HS-2005S-N, Gimpo-si, Korea) was used for the separation experiment. First, the mixture of MSA and $\mathrm{H}_{2} \mathrm{O}$ was placed in a round flask and distilled at $80 \mathrm{RPM}$ for $3 \mathrm{~h}$. The heating medium was silicone oil and the temperature of the coolant was $4{ }^{\circ} \mathrm{C}$. As shown in Table 1, the heating temperatures of silicone oil for fractional distillation were 100, 150, and $200{ }^{\circ} \mathrm{C}$ and are indicated in (a), (b), and (c), respectively. The detailed experimental conditions are shown in Table 1.

Table 1. Experimental conditions of the fractional distillation process. MSA: methanesulfonic acid.

\begin{tabular}{cccc}
\hline Contents & (a) & (b) & (c) \\
\hline Distillation temperature $\left({ }^{\circ} \mathrm{C}\right)$ & 100 & 150 & 200 \\
Mixing ratio (MSA: $\left.\mathrm{H}_{2} \mathrm{O}\right)$ & & $1: 1$ & \\
Heating medium & \multicolumn{3}{c}{ Silicone oil } \\
Time (hr) & 3 & \\
Flask rotation speed $(\mathrm{RPM})$ & 80 & \\
Coolant temperature $\left({ }^{\circ} \mathrm{C}\right)$ & & 4 & \\
\hline
\end{tabular}

\subsection{Recovery of Ag Using a Separated MSA Solution}

After confirming the optimal conditions for fractional distillation, the Ag recovery process from the solar cells was carried out until four times as described in Section 2.1. To recover Ag leached from the solar cell, $\mathrm{HCl}$ (35 wt.\%) was put into the MSA-based leach solution with stirring at $200 \mathrm{RPM}$ for $1 \mathrm{~h}$. The precipitated $\mathrm{AgCl}$ was separated by centrifugation device. Recovered $\mathrm{AgCl}$ was converted to Ag metal powder by chemical wet process with stirring at $200 \mathrm{RPM}$ for $1 \mathrm{~h}$.

The concentration of Ag in the solution was analyzed by inductively coupled plasma atomic emission spectroscopy (ICP-AES, Shimadzu ICPS-1000IV, Kyoto, Japan). Fourier-transform infrared (FT-IR, Bruker ALPHA-P, Billerica, MA, USA) spectroscopy was used to investigate the qualitative 
analysis of fractionally separated MSA and distilled $\mathrm{H}_{2} \mathrm{O}$. The phases of the recovered $\mathrm{AgCl}$ and converted Ag powder were also analyzed by X-ray diffractometer (XRD, Rigaku DMAX-2500, Tokyo, Japan). Glow discharge mass spectrometer (GDMS, Thermo VG 9000, Waltham, MA, USA) was used to analyze the concentrations of the various impurities in the Ag metal powder.

\section{Results and Discussion}

\subsection{Extraction Behavior of Ag Using Reused Organic Solution}

In the previous experiment, MSA and $\mathrm{H}_{2} \mathrm{O}_{2}$ were mixed and the optimum process was determined [19]. As shown in Figure 1, however, the reactivity of MSA for Ag extraction from solar cells was significantly reduced. The solubility of the $\mathrm{Ag}$ in the reused solution was reduced by about $15 \%$ even though the experiment was conducted for up to $12 \mathrm{~h}$. This is because $\mathrm{H}_{2} \mathrm{O}$ was formed as a side reaction in the Ag extraction process using MSA and $\mathrm{H}_{2} \mathrm{O}_{2}$. The mechanism of the chemical reaction used to extract $\mathrm{Ag}$ with $\mathrm{MSA}$ and $\mathrm{H}_{2} \mathrm{O}_{2}$ is shown as follows [23].

$$
\begin{gathered}
2 \mathrm{Ag}+\mathrm{H}_{2} \mathrm{O}_{2} \rightarrow \mathrm{Ag}_{2} \mathrm{O}+\mathrm{H}_{2} \mathrm{O} \\
\mathrm{Ag}_{2} \mathrm{O}+2 \mathrm{CH}_{3} \mathrm{SO}_{3} \mathrm{H} \rightarrow 2 \mathrm{CH}_{3} \mathrm{SO}_{3} \mathrm{Ag}+\mathrm{H}_{2} \mathrm{O} \\
2 \mathrm{CH}_{3} \mathrm{SO}_{3} \mathrm{H}+2 \mathrm{Ag}+\mathrm{H}_{2} \mathrm{O}_{2} \rightarrow 2 \mathrm{CH}_{3} \mathrm{SO}_{3} \mathrm{Ag}+2 \mathrm{H}_{2} \mathrm{O}
\end{gathered}
$$

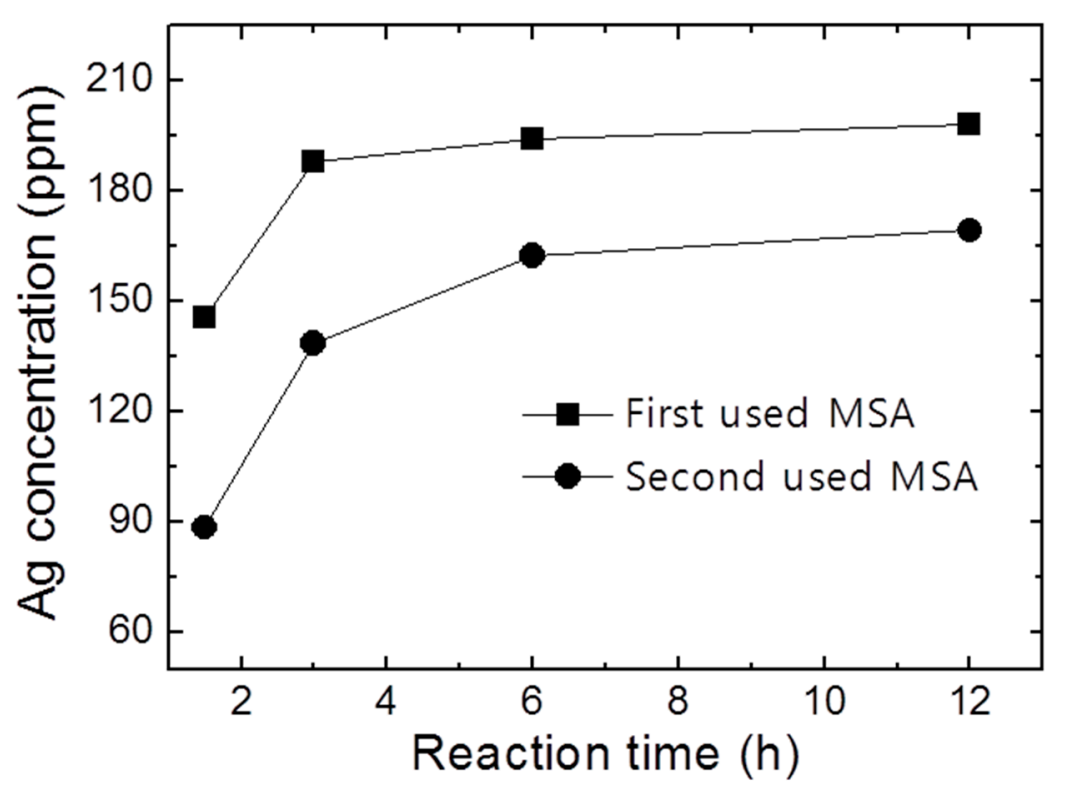

Figure 1. The results ofICP-AES analysis depending on the extraction behavior of the first used MSA and the second used MSA.

The $\mathrm{H}_{2} \mathrm{O}$ generated by the side reaction lowers the concentration of MSA, which reduces the extraction reactivity of $\mathrm{Ag}$ from the solar cell. In an acidic environment, in addition, $\mathrm{H}_{2} \mathrm{O}_{2}$ further decomposes into $\mathrm{H}_{2} \mathrm{O}$ and $\mathrm{O}_{2}$ due in an acid-catalyzed reaction [24]. In an acidic solution, it is possible for $\mathrm{H}_{2} \mathrm{O}_{2}$ to be decomposed and become diluted solution due to the formation of $\mathrm{H}_{2} \mathrm{O}$ [25].

$$
\mathrm{H}_{2} \mathrm{O}_{2}+\mathrm{H} \rightarrow \mathrm{H}_{2} \mathrm{O}+1 / 2 \mathrm{O}_{2}+\mathrm{H}
$$

It is important to develop methods to control the $\mathrm{H}_{2} \mathrm{O}$ in solution because it has very strong effects on the physicochemical properties of acid [26]. Reduced reactivity with Ag in MSA solution is attributed to an increased amount of $\mathrm{H}_{2} \mathrm{O}$, which results in a lower Ag dissolution rate from the solar cell. Also, MSA is hygroscopic and the process of extracting Ag requires a relatively long process time. 
Therefore, more $\mathrm{H}_{2} \mathrm{O}$ can be added to the MSA solution during the process. As a result, the reactivity of reused MSA is significantly lowered in the Ag extraction process.

\subsection{Fractional Distillation Behavior of an Organic Solvent and $\mathrm{H}_{2} \mathrm{O}$ Mixture}

Table 2 shows the fractional distillation behavior according to process conditions. We can use this process to separate a mixture of two miscible liquids that have boiling points that are different to each other. This process is carried out using a rotary evaporator apparatus. This method can separate a mixture of MSA (boiling point is about $290^{\circ} \mathrm{C}$ ) and $\mathrm{H}_{2} \mathrm{O}$ (boiling point is $100^{\circ} \mathrm{C}$ ) at $1 \mathrm{~atm}$, respectively. In the case of (a) and (b), the fractional distillation was not affected much. However, in the case of (c), MSA and $\mathrm{H}_{2} \mathrm{O}$ were almost separated. In the case of (a) in which the fractional distillation temperature was $100{ }^{\circ} \mathrm{C}$, the distilled $\mathrm{H}_{2} \mathrm{O}$ was only $110 \mathrm{~mL}$ and the remaining MSA was $490 \mathrm{~mL}$. In the case of (b) in which the distillation temperature was $150{ }^{\circ} \mathrm{C}$, it was confirmed that MSA still contained a large amount of $\mathrm{H}_{2} \mathrm{O}$, although the distilled $\mathrm{H}_{2} \mathrm{O}$ increased to $200 \mathrm{~mL}$. In the case of (c) in which the fractional distillation temperature was $200{ }^{\circ} \mathrm{C}$, it was found that the distilled $\mathrm{H}_{2} \mathrm{O}$ was $290 \mathrm{~mL}$ and the remaining MSA was $310 \mathrm{~mL}$. It was confirmed that the amount of separated MSA did not change after $3 \mathrm{~h}$ in all conditions. It can be seen that a temperature of about $200^{\circ} \mathrm{C}$ is required for the $\mathrm{H}_{2} \mathrm{O}$ mixed with the MSA to be sufficiently separated.

Table 2. The amount of residual MSA and $\mathrm{H}_{2} \mathrm{O}$ distilled by the following process conditions: (a) $100{ }^{\circ} \mathrm{C}$, (b) $150{ }^{\circ} \mathrm{C}$ and (c) $200{ }^{\circ} \mathrm{C}$.

\begin{tabular}{cccc}
\hline Contents & (a) & (b) & (c) \\
\hline Residual MSA $(\mathrm{mL})$ & 490 & 400 & 310 \\
Distilled $\mathrm{H}_{2} \mathrm{O}(\mathrm{mL})$ & 110 & 200 & 290 \\
\hline
\end{tabular}

Table 3 shows the location wavenumber and description of the MSA- $\mathrm{H}_{2} \mathrm{O}$ system to allow for a better understanding of the FTIR analysis results. It is based on various literature cited [27-33]. The FTIR analysis results, which were obtained through before and after fractional distillation, are shown in Figures 2 and 3. Pure MSA, MSA $+\mathrm{H}_{2} \mathrm{O}$, and separated MSA were analyzed by FTIR to investigate the reactivity behavior of MSA. Figure 2a shows typical FTIR peaks of pure MSA $[25,26]$. There were $\mathrm{CH}_{3}$ bands at 3030, 2940,1415, and $980 \mathrm{~cm}^{-1}, \mathrm{SO}_{3}$ bands at 1320 and $1120 \mathrm{~cm}^{-1}$, a S-OH stretch vibration at $880 \mathrm{~cm}^{-1}$, and a C-S stretch vibration at $760 \mathrm{~cm}^{-1}$, as shown in Table 3 . In the case of Figure 2b, the height of the FTIR peak was lowered overall, except for the $\mathrm{C}-\mathrm{S}$ stretch vibration at $780 \mathrm{~cm}^{-1}$, because the MSA was mixed with $\mathrm{H}_{2} \mathrm{O}$. In Figure 2c, on the other hand, we can see that the result of the FTIR analysis line is located in the middle of Figure 2a,b at parts of the $\mathrm{CH}_{3}$ and $\mathrm{SO}_{3}$ band and the C-OH stretch vibration at 3030, 2940, 1320, 1120, and $880 \mathrm{~cm}^{-1}$. It is considered that the result of the restoration of the reactivity of MSA was due to fractional distillation. Generally, the intrinsic physicochemical properties of the corresponding molecule can be confirmed by the wavenumber of each IR absorption peak [34]. The $\mathrm{f}$ actor that determines the peak intensity in the infrared spectra is the concentration of molecules in the sample [35]. In other words, the concentration of the sample is related to the height of the FTIR peak. The height of the peak increases as the concentration of the analytical sample increases. For this reason, the IR peak of Figure 2c, which corresponds to separated MSA, is in the middle of Figure 2a (pure MSA) and Figure $2 b$ (MSA mixed with $\mathrm{H}_{2} \mathrm{O}$ ). This result indicates that fractional distillation increases the MSA concentration, which means that the reactivity with $\mathrm{Ag}$ can be restored. Meanwhile, pure $\mathrm{H}_{2} \mathrm{O}$ and distilled $\mathrm{H}_{2} \mathrm{O}$ by fractional distillation are shown in Figure 3a,b. Pure $\mathrm{H}_{2} \mathrm{O}$ and distilled $\mathrm{H}_{2} \mathrm{O}$ showed differences in FTIR analysis results. First, the height of the $\mathrm{O}-\mathrm{H}$ stretch at $3320 \mathrm{~cm}^{-1}$ of the distilled $\mathrm{H}_{2} \mathrm{O}$ was found to be lower than that pure $\mathrm{H}_{2} \mathrm{O}$, because the other components were mixed in the distilled $\mathrm{H}_{2} \mathrm{O}$. In addition, the $\mathrm{SO}_{2}$ band was found at $1180 \mathrm{~cm}^{-1}$, the $\mathrm{SO}_{3}$ band was found at $1050 \mathrm{~cm}^{-1}$ and the C-S vibration was found at $780 \mathrm{~cm}^{-1}$ in the FTIR analysis of the distilled $\mathrm{H}_{2} \mathrm{O}$. This means that MSA is also decomposed during fractional distillation process. 
Table 3. Location of relevant indicator bands in the MSA- $\mathrm{H}_{2} \mathrm{O}$ system.

\begin{tabular}{cc}
\hline Location Wavenumber $\left.\mathbf{( c m}^{-\mathbf{1}}\right)$ & Description \\
\hline $3000-3400$ & O-H stretch \\
3030 & $\mathrm{CH}_{3}$ asymmetric stretch \\
2940 & $\mathrm{CH}_{3}$ asymmetric stretch \\
1630 & $\mathrm{O}-\mathrm{H}$ bend \\
1415 & $\mathrm{CH}_{3}$ asymmetric bend \\
1320 & $\mathrm{SO}_{3}$ asymmetric stretch \\
1180 & $\mathrm{SO}_{2}$ asymmetric stretch \\
1120 & $\mathrm{SO}_{3}$ symmetric stretch \\
1050 & $\mathrm{SO}_{3}$ symmetric stretch \\
980 & CH $H_{3}$ rock \\
880 & S-OH stretch \\
780 & $\mathrm{C}-\mathrm{S}$ symmetric stretch \\
760 & $\mathrm{C}-\mathrm{S}$ symmetric stretch \\
\hline
\end{tabular}

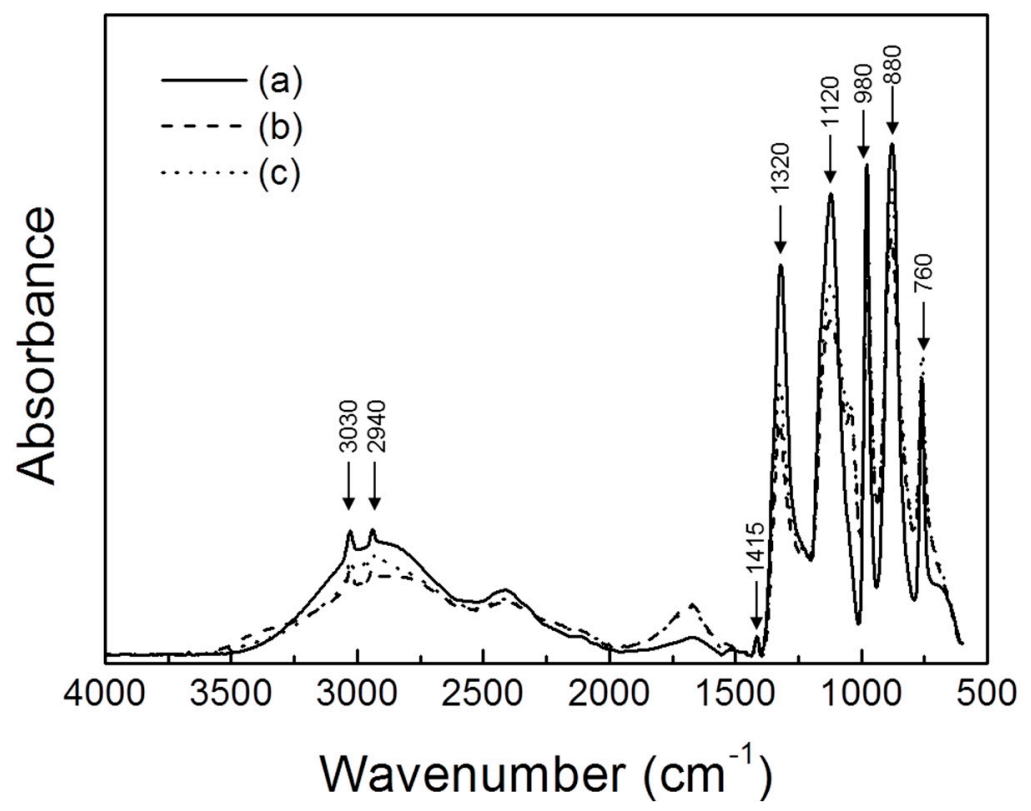

Figure 2. Results of FTIR analysis before and after the fractional distillation: (a) pure MSA, (b) MSA and $\mathrm{H}_{2} \mathrm{O}$ mixture, and (c) separated MSA.

\subsection{Recovery of Ag from Organic Solvent with Restored Reactivity}

We confirmed that concentration of MSA can be restored by fractional distillation as a result of FTIR. Figure 4 shows the Ag extraction behavior by repeated use of MSA by ICP-AES analysis as a function of the reaction time. The yellow dotted line in Figure 4 indicates that $\mathrm{Ag}$ is entirely dissolved in the solution. From this, we can see that in all the cases where MSA was reused, the yellow line is reached within $4 \mathrm{~h}$. It is indicated that the reactivity of MSA and Ag was improved by all fractional distillation experiments. In other words, the MSA concentration was restored through fractional distillation, and it was confirmed that the Ag could be dissolved in the reused MSA. 


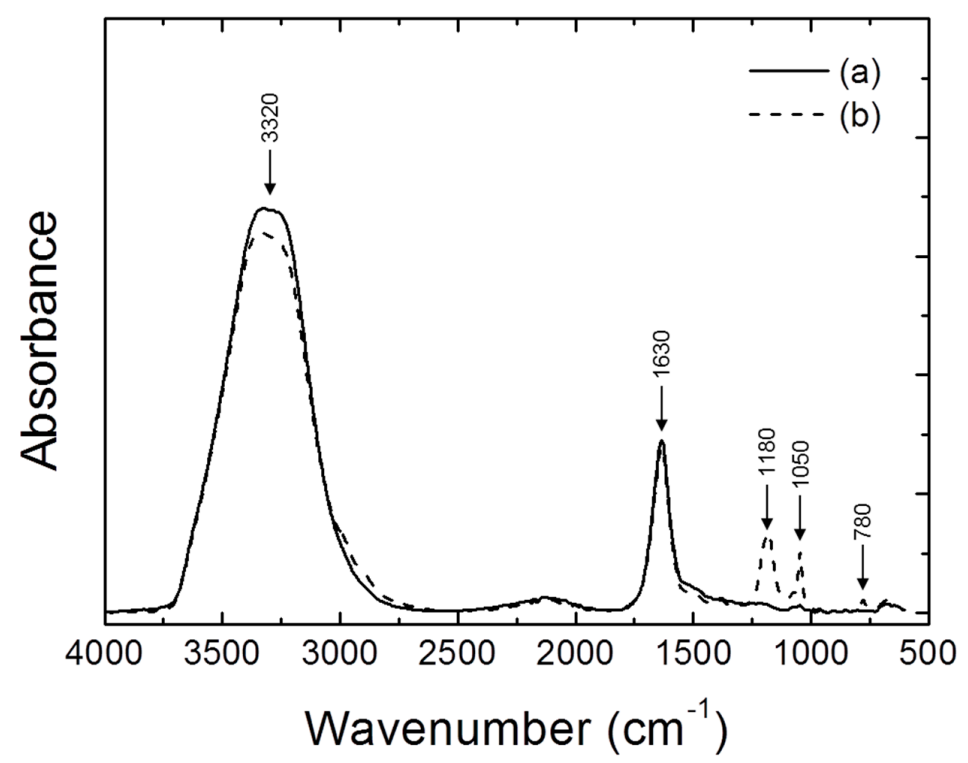

Figure 3. Results of FTIR analysis before and after the fractional distillation: (a) pure $\mathrm{H}_{2} \mathrm{O}$ and (b) distilled $\mathrm{H}_{2} \mathrm{O}$ by fractional distillation.

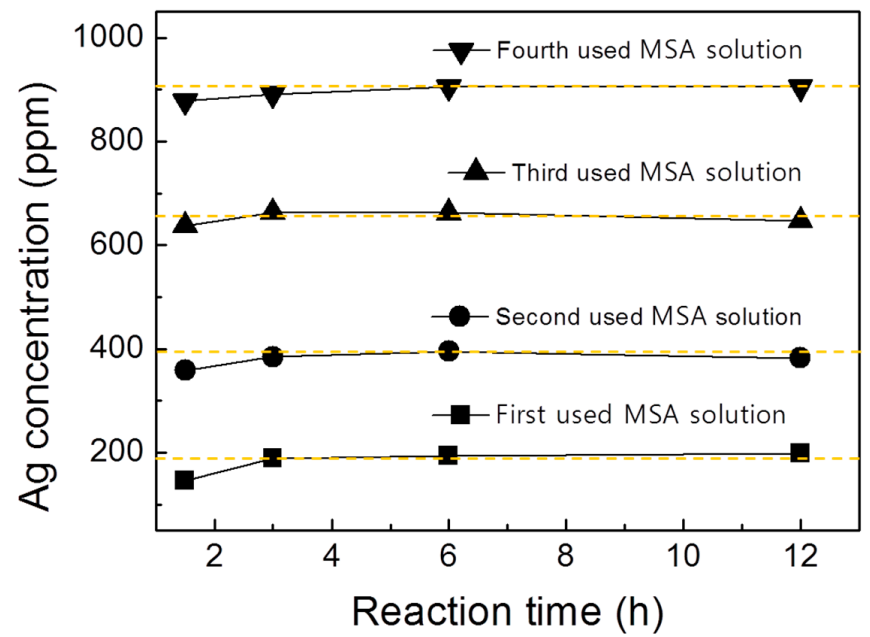

Figure 4. Ag extraction behavior by repeated use of MSA by ICP-AES analysis. The marked yellow dashed line represents the theoretical solubility of Ag.

Figure 5 shows the $\mathrm{XRD}$ spectrums of $\mathrm{AgCl}$ recovered and $\mathrm{Ag}$ converted from $\mathrm{AgCl}$ by a wet chemical process. The converted Ag powder only shows the phase of Ag. As a result, pure Ag powder can be obtained using this simple chemical process. Table 4 provides a summary of the GDMS results for the purity levels of the as-recovered Ag powders. It can be confirmed that the Ag metal converted from $\mathrm{AgCl}$ had a purity of $\sim 99.5 \%(2 \mathrm{~N})$, with an especially large amount of $\mathrm{Cl}$ and $\mathrm{Pb}$ present in the recovered $\mathrm{Ag}$ as impurities. It is expected that $\mathrm{Pb}$ dissolved due to the reaction of MSA solution and $\mathrm{Pb}$. This is because $\mathrm{Pb}$ exists as a glass frit together with the Ag present in the solar cell [36]. Not only $\mathrm{Ag}$ but $\mathrm{Pb}$ also dissolves well in the MSA and $\mathrm{H}_{2} \mathrm{O}_{2}$ solution [37]. The dissolved $\mathrm{Pb}$ is considered to be precipitated together with $\mathrm{PbCl}_{2}$ when $\mathrm{AgCl}$ is leached by $\mathrm{HCl}$ [38]. For this reason, $\mathrm{Pb}$ and $\mathrm{Cl}$ were detected as $480 \mathrm{ppm}$ and $4000 \mathrm{ppm}$ in the GDMS analysis, respectively. In addition, it is expected that a large amount of $\mathrm{Cl}$ was detected in the $\mathrm{Ag}$ powder because not all of the $\mathrm{AgCl}$ was converted to $\mathrm{Ag}$. As a result, 2N-grade Ag could be recovered from solar cells and it would be possible to recover higher purity $\mathrm{Ag}$ through the optimization condition of $\mathrm{Ag}$ conversion from $\mathrm{AgCl}$ and additional processes such as the electrochemical method. 


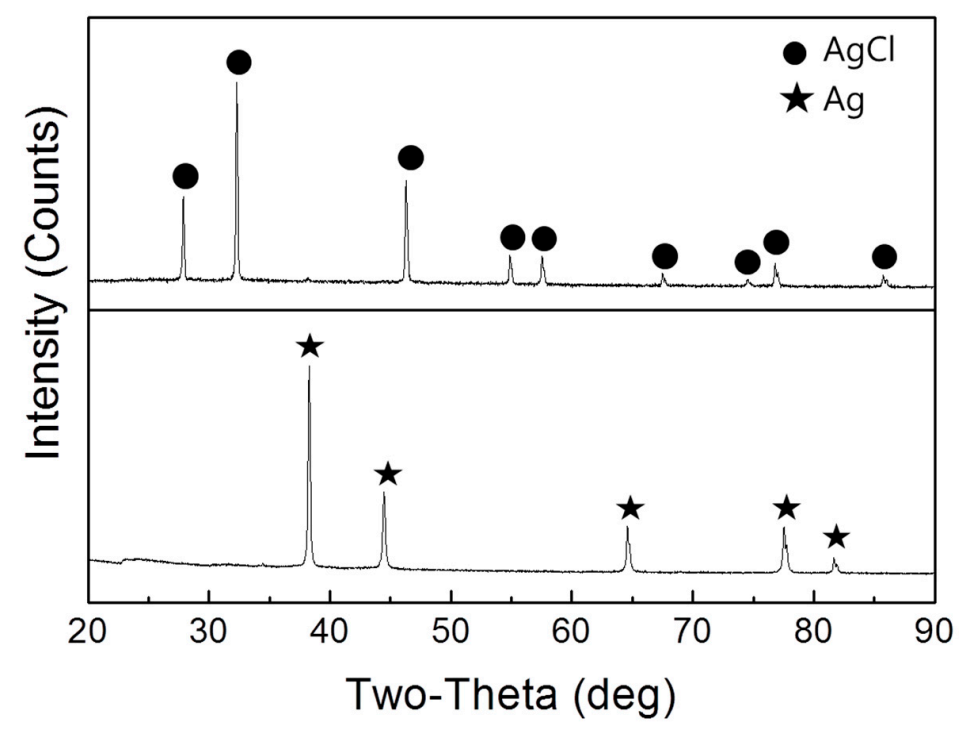

Figure 5. The XRD spectrums of $\mathrm{AgCl}$ recovered and $\mathrm{Ag}$ converted from $\mathrm{AgCl}$ by a wet chemical process.

Table 4. The purity levels of the as-recovered Ag powders.

\begin{tabular}{cccc}
\hline Elements & Concentration (ppmw) & Elements & Concentration (ppmw) \\
\hline $\mathrm{Be}$ & $<0.001$ & $\mathrm{Cr}$ & 0.76 \\
$\mathrm{~B}$ & 0.89 & $\mathrm{Mn}$ & 0.42 \\
$\mathrm{Na}$ & 3.4 & $\mathrm{Fe}$ & 16 \\
$\mathrm{Mg}$ & 0.71 & $\mathrm{Co}$ & 0.01 \\
$\mathrm{Al}$ & 4.8 & $\mathrm{Ni}$ & 0.89 \\
$\mathrm{Si}$ & 65 & $\mathrm{Cu}$ & 2 \\
$\mathrm{P}$ & 38 & $\mathrm{Zn}$ & 0.36 \\
$\mathrm{~S}$ & 0.5 & $\mathrm{Ga}$ & $<0.1$ \\
$\mathrm{Cl}$ & $\mathrm{Ge}$ & $<0.1$ \\
$\mathrm{~K}$ & 4000 & $\mathrm{Ag}$ & Matrix \\
$\mathrm{Ca}$ & 0.71 & $\mathrm{Sn}$ & 2.8 \\
$\mathrm{Ti}$ & 1.1 & $\mathrm{~Pb}$ & 480 \\
\hline
\end{tabular}

\section{Conclusions}

MSA, an environmentally friendly organic acid, was used to recover Ag from solar cells. MSA is highly soluble, environmentally friendly, and easy to handle. However, when Ag is recovered using MSA and $\mathrm{H}_{2} \mathrm{O}_{2}$, a side reaction that generates $\mathrm{H}_{2} \mathrm{O}$ occurs and $\mathrm{H}_{2} \mathrm{O}_{2}$ decomposes in $\mathrm{H}_{2} \mathrm{O}$ under acidic conditions. Furthermore, because MSA is hygroscopic, the concentration of MSA decreased after the Ag extraction reaction, and the reactivity with Ag decreased. In order to improve the reactivity with $\mathrm{Ag}$ and to be able to reuse the MSA solution, fractional distillation was applied as a method to separate MSA and $\mathrm{H}_{2} \mathrm{O}$. MSA and $\mathrm{H}_{2} \mathrm{O}$ were separated at a fractional distillation temperature of $200{ }^{\circ} \mathrm{C}$, and MSA could be reused for recovering Ag. The Ag extracted from the solar cells was recovered in the form of $\mathrm{AgCl}$, and the $\mathrm{Ag}$ was converted through the chemical wet process. The purity of converted $\mathrm{Ag}$ was $99.5 \%$, and it was confirmed that $\mathrm{Pb}$ and $\mathrm{Cl}$ existed as impurities in the converted $\mathrm{Ag}$. However, it may be possible to recover higher purity $\mathrm{Ag}$ from solar cells through the optimization conversion condition of Ag and additional process such as the electrorefining process.

Author Contributions: Conceptualization: J.-K.L. and J.-S.L.; formal analysis: J.-K.L.; investigation: J.-K.L. and J.-S.L.; writing-original draft preparation: J.-K.L.; writing-review and editing: J.-S.L., Y.-S.A., and G.-H.K.; funding acquisition: J.-S.L.

Funding: This research was funded by the Ministry of Trade, Industry and Energy (MOTIE) and Korea Institute for Advancement of Technology (KIAT) through the International Cooperative R\&D program (P0005441_Remanufacturing system of photovoltaic module with material recovered from end-of-life photovoltaic 
module). Further support came from the Research and Development Program of the Korea Institute of Energy Research (KIER) (B5-2464).

Acknowledgments: This research was financially supported by the Ministry of Trade, Industry and Energy (MOTIE) and Korea Institute for Advancement of Technology (KIAT) through the International Cooperative R\&D program (P0005441_Remanufacturing system of photovoltaic module with material recovered from end-of-life photovoltaic module). Further support came from the Research and Development Program of the Korea Institute of Energy Research (KIER) (B5-2464).

Conflicts of Interest: The authors declare no conflict of interest. The funders had no role in the design of the study; in the collection, analyses, or interpretation of data; in the writing of the manuscript, or in the decision to publish the results.

\section{References}

1. Cucchiella, F.; D'Adamo, I.; Rosa, P. End-of-Life of used photovoltaic modules: A Financial analysis. Renew. Sustain. Energy Rev. 2015, 47, 552-561. [CrossRef]

2. Tao, J.; Yu, S. Review on feasible recycling pathways and technologies of solar photovoltaic modules. Sol. Energy Mater. Sol. Cells 2005, 141, 108-124. [CrossRef]

3. Weckend, S.; Wade, A.; Heath, G. End-of-Life Management: Solar Photovoltaic Panels; No. NREL/BK-6A20-66178; National Renewable Energy Lab. (NREL): Golden, CO, USA, 2016.

4. Directive 2012/19/EU of the European Parliament and of the Council of 4 July 2012 on waste electrical and electronic equipment, WEEE. Off. J. Eur. Union 2012, 197, 38-71.

5. Shin, J.; Park, J.; Park, N. A method to recycle silicon wafer from end-of-life photovoltaic module and solar panels by using recycled silicon wafers. Sol. Energy Mater. Sol. Cells 2017, 162, 1-6. [CrossRef]

6. Klugmann-Radziemska, E.; Ostrowski, P. Chemical treatment of crystalline silicon solar cells as a method of recovering pure silicon from photovoltaic modules. Renew. Energy 2010, 35, 1751-1759. [CrossRef]

7. Kang, S.; Yoo, S.; Lee, J.; Boo, B.; Ryu, H. Experimental investigations for recycling of silicon and glass from waste photovoltaic modules. Renew. Energy 2012, 47, 152-159. [CrossRef]

8. Strachala, D.; Hylský, J.; Vaněk, J.; Fafilek, G.; Jandová, K. Methods for recycling photovoltaic modules and their impact on environment and raw material extraction. Acta Montan. Slov. 2017, 22, 257-269.

9. Klugmann-Radziemska, E.; Ostrowski, P.; Drabczyk, K.; Panek, P.; Szkodo, M. Experimental validation of crystalline silicon solar cells recycling by thermal and chemical methods. Sol. Energy Mater. Sol. Cells 2010, 94, 2275-2282. [CrossRef]

10. Olson, C.; Geerligs, B.; Goris, M.; Bennett, I.; Clyncke, J. Current and future priorities for mass and material in silicon PV module recycling. In Proceedings of the 28th European Photovoltaic Solar Energy Conference and Exhibition (28th EU PVSEC), Villepinte, France, 30 September-4 October 2013.

11. Nieland, S.; Neuhaus, U.; Pfaff, T.; Radlein, E. New approaches for component recycling of crystalline solar modules. In Proceedings of the Electronics Goes Green 2012+ (EGG), Berlin, Germany, 9-12 September 2012; pp. 1-5.

12. Palitzsch, W.; Loser, U. A new and intelligent de-metalization step of broken silicon cells and silicon cell production waste in the recycling procedure of crystalline Si modules. In Proceedings of the 37th IEEE Photovoltaic Specialists Conference (PVSC), Seattle, WA, USA, 19-24 June 2011.

13. Dias, P.; Javimczik, S.; Benevit, M.; Veit, H.; Bernardes, A.M. Recycling WEEE: Extraction and concentration of silver from waste crystalline silicon photovoltaic modules. Waste Manag. 2016, 57, 220-225. [CrossRef]

14. Yi, Y.K.; Kim, H.S.; Tran, T.; Hong, S.K.; Kim, M.J. Recovering valuable metals from recycled photovoltaic modules. J. Air Waste Manag. Assoc. 2014, 64, 797-807. [CrossRef]

15. Lee, J.K.; Lee, J.S.; Ahn, Y.S.; Kang, G.H. Effect of current density on morphology of silver thin film recovered from crystalline silicon solar cell by electrochemical process. Thin Solid Films 2018, 663, 143-147. [CrossRef]

16. Klugmann-Radziemska, E. Recycling of Photovoltaic Solar Cells and Modules-Te State-of-Art; Lambert Academic Publishing: Riga, Latvia, 2014.

17. Lee, C.H.; Hung, C.E.; Tsai, S.L.; Popuri, S.R.; Liao, C.H. Resource recovery of scrap silicon solar battery cell. Waste Manag. Res. 2013, 31, 518-524. [CrossRef] [PubMed]

18. Kuczyńska-Łażewska, A.; Klugmann-Radziemska, E.; Sobczak, Z.; Klimczuk, T. Recovery of silver metallization from damaged silicon cells. Sol. Energy Mater. Sol. Cells 2018, 176, 190-195. [CrossRef] 
19. Yang, E.H.; Lee, J.K.; Lee, J.S.; Ahn, Y.S.; Kang, G.H.; Cho, C.H. Environmentally friendly recovery of Ag from end-of-life c-Si solar cell using organic acid and its electrochemical purification. Hydrometallurgy 2017, 167, 129-133. [CrossRef]

20. Gernon, M.D.; Wu, M.; Buszta, T.; Janney, P. Environmental benefits of methanesulfonic acid. Comparative properties and advantages. Green Chem. 1999, 1, 127-140. [CrossRef]

21. Ogata, H.; Tanaka, N. Reduction of waste in semiconductor manufacturing plant (sulfuric acid recycling technology). Glob. Environ. Oki Tech. Rev. 1998, 63, 41-44.

22. Fong, S.S.; Seng, L.; Mat, H.B. Reuse of nitric acid in the oxidative pretreatment step for preparation of humic acids from low rank coal of Mukah, Sarawak. J. Braz. Chem. Soc. 2007, 18, 41-46. [CrossRef]

23. Colvin, A.E., Jr.; Jiang, H. Integrated Catalytic Protection of Oxidation Sensitive Materials. U.S. Patent 9,681,824, 6 June 2017.

24. Kim, T.; Hwang, J.S.; Kwon, S. A MEMS methanol reformer heated by decomposition of hydrogen peroxide. Lab Chip 2007, 7, 835-841. [CrossRef]

25. Kim, E.H.; Kim, Y.H.; Chung, D.Y.; Shin, Y.J.; Yoo, J.H.; Choi, C.S. Decomposition of hydrogen peroxide in the aqueous solution. Korean J. Chem. Eng. 1996, 34, 249-252.

26. Roitman, D.B.; McAlister, J.; Oaks, F.L. Composition characterization of methanesulfonic acid. J. Chem. Eng. Data 1994, 39, 56-60. [CrossRef]

27. Gerakines, P.A.; Schutte, W.A.; Greenberg, J.M.; van Dishoeck, E.F. The infrared band strengths of $\mathrm{H}_{2} \mathrm{O}, \mathrm{CO}$ and $\mathrm{CO}_{2}$ in laboratory simulations of astrophysical ice mixtures. arXiv 1994, arXiv:astro-ph/9409076.

28. Sumathi, S.; Sethuprakash, V.; Basirun, W.J.; Zainol, I.; Sookhakian, M. Polyacrylamide-methanesulfonic acid gel polymer electrolytes for tin-air battery. J. Sol-Gel Sci. Technol. 2014, 69, 480-487. [CrossRef]

29. Nishino, N.; Arquero, K.D.; Dawson, M.L.; Finlayson-Pitts, B.J. Infrared studies of the reaction of methanesulfonic acid with trimethylamine on surfaces. Environ. Sci. Technol. 2014, 48, 323-330. [CrossRef] [PubMed]

30. Fernando, I.P.; Sanjeewa, K.K.; Samarakoon, K.W.; Lee, W.W.; Kim, H.S.; Kim, E.A.; Gunasekara, U.K.D.S.S.; Abeytunga, D.T.U.; Nanayakkara, C.; de Silva, E.D.; et al. FTIR characterization and antioxidant activity of water soluble crude polysaccharides of Sri Lankan marine algae. Algae 2017, 32, 75-86. [CrossRef]

31. Santoso, U.T.; Nurmasari, R.; Umaningrum, D.; Santosa, S.J.; Rusdiarso, B.; Siswanta, D. Immobilization of humic acid onto chitosan using tosylation method with 1, 4-butanediol as a spacer arm. Indones. J. Chem. 2011, 12, 35-42. [CrossRef]

32. Zhong, L.; Parker, S.F. Structure and vibrational spectroscopy of methanesulfonic acid. R. Soc. Open Sci. 2018, 5, 181363. [CrossRef] [PubMed]

33. Givan, A.; Loewenschuss, A.; Nielsen, C.J. Infrared spectrum and ab initio calculations of matrix isolated methanesulfonic acid species and its 1:1 water complex. J. Mol. Struct. 2005, 748, 77-90. [CrossRef]

34. Chen, Y.; Zou, C.; Mastalerz, M.; Hu, S.; Gasaway, C.; Tao, X. Applications of micro-fourier transform infrared spectroscopy (FTIR) in the geological sciences-A review. Int. J. Mol. Sci. 2015, 16, 30223-30250. [CrossRef] [PubMed]

35. Iglesias-Groth, S.; Cataldo, F.; Manchado, A. Infrared spectroscopy and integrated molar absorptivity of c60 and c70 fullerenes at extreme temperatures. Mon. Not. R. Astron. Soc. 2011, 413, 213-222. [CrossRef]

36. Shih, Y.C.; Lin, Y.H.; You, J.P.; Shi, F.G. Screen-printable silver pastes with nanosized glass frits for silicon solar cells. J. Electron. Mater. 2013, 42, 410-416. [CrossRef]

37. Zhang, X.; Guan, J.; Guo, Y.; Cao, Y.; Guo, J.; Yuan, H.; Su, R.; Liang, B.; Gao, G.; Zhou, Y.; et al. Effective dismantling of waste printed circuit board assembly with methanesulfonic acid containing hydrogen peroxide. Environ. Prog. Sustain. Energy 2017, 36, 873-878. [CrossRef]

38. Zuckerman, J.J. Inorganic Reactions and Methods: The Formation of Bonds to Halogens; John Wiley \& Sons: Hoboken, NJ, USA, 2009; Volume 4.

(C) 2019 by the authors. Licensee MDPI, Basel, Switzerland. This article is an open access article distributed under the terms and conditions of the Creative Commons Attribution (CC BY) license (http://creativecommons.org/licenses/by/4.0/). 